УДК 007.3

Olena Lisitsyna

Олена Лісіцина

\title{
FIXED VERSUS FLEXIBLE - GUESS WHO WINS?
}

The article is devoted to the problem of fixed price, time and materials pricing models on outsource projects of software development. Based on real experience of big IT company there are ready solutions how to deal with that issue and make a right choice along with how to prevent unexpected budget increase on specific project. Among necessary steps to achieve this goal there are the following ones: technical specification writing with such deliverables as user stories, wires, clickable prototypes, test plan, project plan, and a detailed estimate of the project; calculating of predictable and unpredictable risks (along with definition of the ways how to do that), the work on agreements base that includes Change Order agreement. The conclusion is that good communication of these preventing steps at the very beginning of project conversations is extremely important.

Keywords: outsource project, fixed price, time and materials, specification writing, unpredictable risk.

Introduction. A lot of stuff has been already written about the issue of fixed price, time and materials budget models for the projects of software development. Best resources that have been researched while writing this article you can find in references [1-3]. No doubt this is a really important issue that every project/product manager in IT deals with on daily basis. The reply to the question: "Why?" is very simple - it's all about money, project budget and profit of the company. A known fact is that there are three main pricing models: fixed price (or fixed scope), time and materials and body leasing. Every software outsourcing company chooses what to use in every specific case for particular customer. Every customer and vendor who works on fixed scope scenario knows what risks are coming down the road but not everybody knows how to prevent them and how to choose a proper way to go among these three at the beginning. References give us a sense what is what but not necessarily a prioritization of the suggestions that project manager should come up with for the customer to make his project successful and profitable.

It looks like every project/product manager has a dream to have all the projects that use a time and materials pricing model.

Meanwhile there is a huge number of clients who develop an uneasy feeling that they're being deceived when they see another unexpected bill for what the outsource team calls "extra scope". Such customer experienced "scope creep" too many times.

As the COO of a large outsourcing company, we've seen a large number of clients that have experienced these two scenarios. It's not a pleasant experience for any of them.

How to find a solution to solve this problem? This article is based on real experience at an IT company that has replied to this question.

Problem and solution. The classic situation for most fixed price cases looks like this (table 1).

Table 1

\begin{tabular}{|l|l|}
\hline \multicolumn{1}{|c|}{ Customer } & \multicolumn{1}{c|}{ Vendor } \\
\hline $\begin{array}{l}\text { Planned budget has gone down the drain } \\
\text { My budget is already used up! }\end{array}$ & $\begin{array}{l}\text { We are again out of scope, an endless stream of request } \\
\text { changes }\end{array}$ \\
\hline $\begin{array}{l}\text { Why should I continue to pay for something that } \\
\text { the project manager forgot to include? }\end{array}$ & $\begin{array}{l}\text { Why does she not understand that we didn't estimate for } \\
\text { that additional scope? }\end{array}$ \\
\hline $\begin{array}{l}\text { The project deadline is postponed for another two } \\
\text { weeks, costing me more time and money! }\end{array}$ & My developers are already planning for the next project! \\
\hline $\begin{array}{l}\text { We have a signed agreement and the project team } \\
\text { is not honoring it! }\end{array}$ & $\begin{array}{l}\text { Why didn't she tell us anything about her deadline for } \\
\text { the demos, events, and other commitments from at the } \\
\text { very beginning of our conversations? }\end{array}$ \\
\hline
\end{tabular}


After many trials and errors, we've learned what is the best way to meet our clients needs and still make a profit. The step-by-step process can be found below:

A spec requirements document is a "must have" with all fixed price projects. Even if a company has already spent 100,000 USD on a project, most development agencies need to start all over again from scratch. The reason is that people who aren't developers do not understand how to put together a quality spec requirements document.

Timeline: $2-3$ weeks.

Budget: $2,000-3,000$ USD.

The purpose is to minimize mistakes, prevent cost overruns and to reduce risk. This can create the best possible scenario so that the customer is happy and willing to refer other clients in the future. Written specs help both the development team and the client to understand what exactly needs to be developed, how and why (what programming language, framework and other development tools to use; what is business logics of all the functionality units; what is business proposal and business values within the project).

Deliverables: user stories, wires, clickable prototype (what tool to use can be found under [4]), test plan, project plan, and a detailed estimate that includes EXACT budget numbers. Based on our experience, the average increase in hours from original scope in this case is usually between 3-7\%. If customer needs to have development work done and doesn't want to spend a little extra money upfront to understand all of the "whats" and "hows" - he/she should be prepared to spend at least an additional $30 \%$ over the original agreed upon hours in the contract (again based on real experience).

If customer is still not convinced that the first scenario can happen or he/she is in a hurry and just doesn't want to "waste" two weeks, vendor needs to include a $\sim 30 \%$ cushion for unexpected costs in project budget (again this is based on my experience). These unexpected risks will happen to be sure! For example (dialog between customer and vendor):

- Please change subject line in the email we send after user has been registered in the system.

- Sir, we need 0.5 hours to do that.

- What? Why? It's just copy and paste action.

- Yeah, but we need to find where to do change it, then make the change, test it and finally deploy it.

Then multiply it by three times at least (subject line can be changed three, four or more times... get ready!

This is just a simple case to illustrate the problem, there are much more complicated issues that no one has through about before project has been started.

What is the difference between predictable (expected) and unpredictable (unexpected) risks? Rough project estimate generally contains min and max estimation range of each project issue [5]. Next to these numbers there will be risk value (that can be counted in 0 through 3 points) and paddings that can have for instance such a formula for its calculation:

$=\mathrm{IF}$ (risk value $=0$, $\max$ hours $* 0, \mathrm{IF}$ (risk value $=1$, max hours $* 0.1, \mathrm{IF}$ (risk value $=2$, max hours $* 0.2, \mathrm{IF}$ (risk value $=3$, $\max$ hours $* 0.4$, "Assess"))))

Then the total additional hourly budget is calculated as the sum of all paddings. A few examples can be found below. In the first case (please refer to the Image 1) predictable risks are 3 and 2 for two issues, the sum of paddings is 18 hours; in the second case (please refer to the Image 2) risks are 3, 3, 1, 2, 3, 2 for six issues, the sum of paddings is 21 hours.

What about unpredictable risks? In fact the issues that have not been included for some reason for the estimate use to be the main problem. Customer and vendor haven't expected them to happen. However they exist and have to be calculated. Please refer to this article to learn more about this issue [6]. To minimize the efforts in order to define and calculate unpredictable risks we suggest to add at least a $\sim 30 \%$ cushion (note: works only for small and mid scale software products). 


\begin{tabular}{|c|c|c|c|c|}
\hline Effort & Min (man hours) & Max (man hours) & Risk $(0-3)$ & Padding \\
\hline Project setup & 3 & 4 & & 0 \\
\hline DB architecture & 8 & 12 & & 0 \\
\hline Setup stage environment, GIT repository & 4 & 6 & & 0 \\
\hline Ul design development & 24 & 36 & 3 & 14.4 \\
\hline \multirow[t]{9}{*}{ Merchant integration } & 8 & 10 & 2 & 2 \\
\hline & & & & 0 \\
\hline & & & & 0 \\
\hline & & & & 0 \\
\hline & & & & 0 \\
\hline & & & & 0 \\
\hline & & & & 0 \\
\hline & & & & 0 \\
\hline & & & & 0 \\
\hline Deploy to production environment & 6 & 8 & 2 & 1.6 \\
\hline & & & & 0 \\
\hline Development effort & 53 & 76 & & 18 \\
\hline Quality assurance (30\%) & 15.9 & 22.8 & & \\
\hline Project management (10\%) & 6.89 & 9.88 & & \\
\hline Estimated hours for release & 75.79 & 108.68 & & 18 \\
\hline Release TOTAL (estimated hours incl padding) & 93.79 & 1220.68 & & \\
\hline
\end{tabular}

Image 1

\begin{tabular}{|c|c|c|c|c|c|}
\hline Effort, (man hours) & Min & Max & & Risk & \\
\hline Project setup: & 1.0 & 2.0 & 3 & 0.8 & \\
\hline Initial setup & 1.0 & 2.0 & 3 & 0.8 & $\begin{array}{l}\text { Project environment setup, project } \\
\text { toolkit creation, project toolkit } \\
\text { support and troubleshooting, staging } \\
\text { environment setup }\end{array}$ \\
\hline Setup stage environment, GIT repository & 4.0 & 3.0 & 1 & 0.3 & \\
\hline DB architecture & 8.0 & 12.0 & 2 & 2.4 & \\
\hline \multicolumn{6}{|l|}{ Design: } \\
\hline UI design development & 24.0 & 36.0 & 3 & 14.4 & Design is not specified yet \\
\hline \multicolumn{6}{|l|}{ Mobile device support } \\
\hline Retina displays support & 8.0 & 10.0 & 2 & 2.0 & Design is not specified yet \\
\hline \multicolumn{6}{|l|}{ <Section Name:> } \\
\hline$<$ Feature Name> & & & & & \\
\hline
\end{tabular}

\begin{tabular}{llll}
\hline Main development effort & 67 & 86 & 21 \\
Unanticipated scope adjustments effort, $30 \%$ & 20 & 26 \\
Quality assurance, 30\% & 26 & 33 \\
Project management, 10\% & 11 & 14 \\
\hline \multicolumn{1}{c}{ Release TOTAL, manhours incl padding } & 124 & 159
\end{tabular}

\section{Image 2}

If the client wants to continue the project and ignore the advice in № 1 and № 2, then he/she should be prepared from the start that the vendor will not do any additional work that is "out-of-scope" if:

a) it is not signed off under a change order agreement [7] and

b) it is not paid one hundred percent upfront.

The customer can still work things out, but he should be aware of these key issues.

A few words about the case when parties sign change order agreement. 
This happens not one or two times during the project, but more than that. In a case "out-of-scope" issues come, that literally happens at least a few times on the fixed price project. That's why the procedure of determining "out-of-scope" issues and signing change order should be clearly explained to the client and be solid. For instance, all "out-of-scope" issues are gathered into a list for some period of time (let's say, two weeks), then vendor estimates them and gives to the customer for approval. If customer approves that to be "out-of-scope" and agrees with estimated time this can be included to the change order agreement № 1. Next two weeks there will be next list of such issues and so on.

The best illustration of the agreements base including change order (please refer to the Image 3 ) for your reference [7].

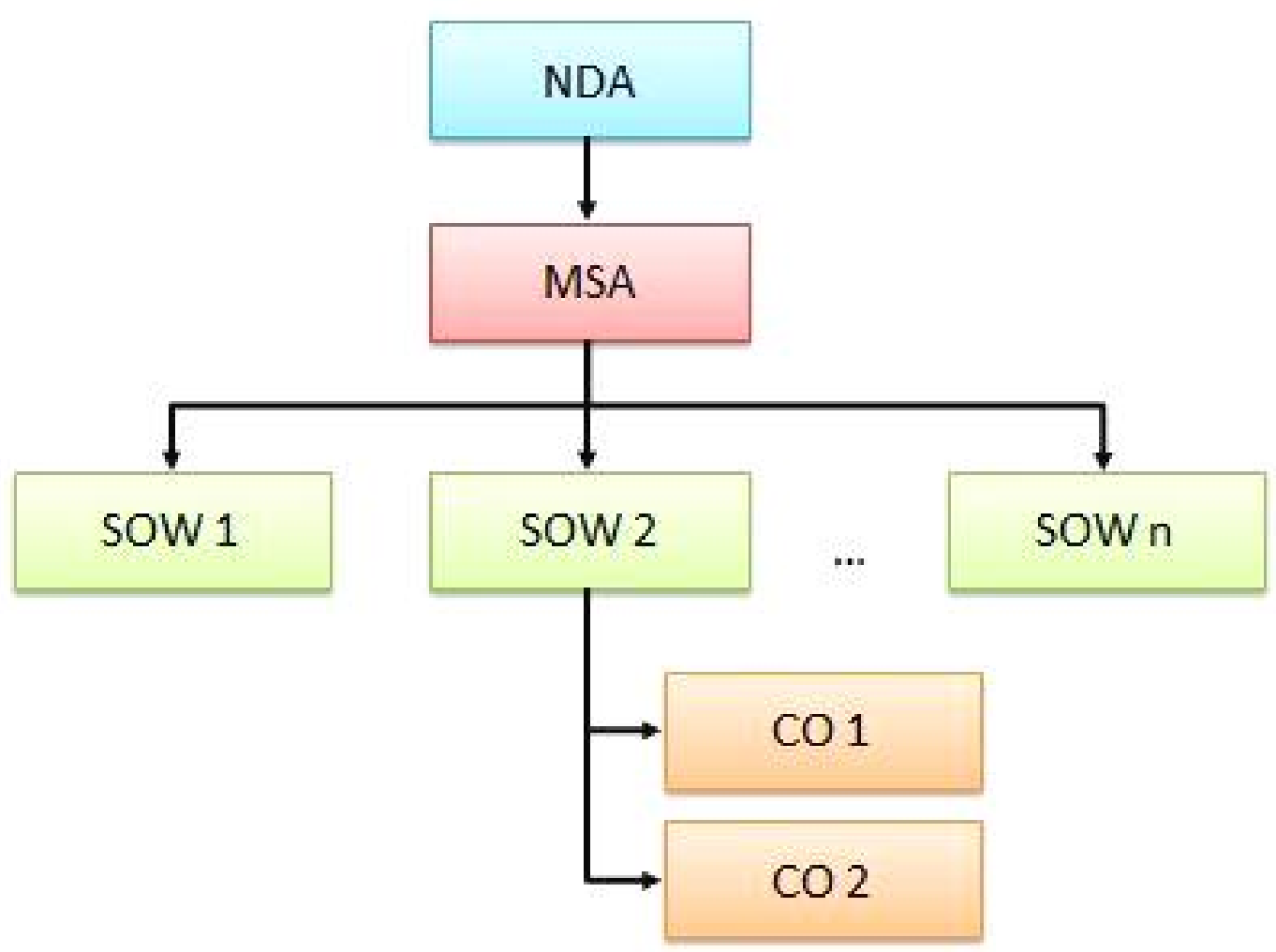

Image 3

Non-Disclosure Agreements (NDA)

Master Services Agreements (MSA)

Statements of Work (SOW)

Change Orders (CO)

We need to underline that this all increases project budget compared to the original one. And that's where all the disappointing comes both for customer and vendor. Customer considers some issues to be in scope when they are not. Vendor has provided all the development efforts to make profit on this work, so such discussions always require some compromise that steals vendor's profit.

Also we should mention that because of lack of understanding how to prevent risks on fixed price projects many outsource companies prefer nowadays work on time and materials with upfront payments (that means vendor actually solves other business problems like finding the customer that also likes this way to work and building a solid trust in the client).

The following matrix (table 2) provides a comparison between time and materials (T\&M) vs fixed price projects, it can help you to understand what is really under these two different payment terms. The information above was all about fixed price model. 
Table 2

\begin{tabular}{|l|l|}
\hline \multicolumn{1}{|c|}{ Time and materials } & \multicolumn{1}{c|}{ Fixed price } \\
\hline $\begin{array}{l}\text { The project is large } \\
\text { The scope is poorly defined and likely to keep } \\
\text { changing }\end{array}$ & $\begin{array}{l}\text { The project is very small (a month or less generally) } \\
\text { The scope is very well defined and unlikely to change }\end{array}$ \\
\hline Good for: long term projects & Good for: MVPs for startups [8], pilot projects \\
\hline $\begin{array}{l}\text { Save time for estimations and work on } \\
\text { specs/wires }\end{array}$ & \\
\hline Accurate agile (scrum) & Waterfall agile \\
\hline Decision flexibility & Less flexibility for change requests \\
\hline Change-driven approach & Plan-driven approach \\
\hline Lower rate & Unpredictable risks included into fixed price model (30\%) \\
\hline Full-time resource availability & Suitable for the demo period \\
\hline Team-oriented cooperation & \\
\hline Flexible reporting format & \\
\hline
\end{tabular}

Conclusion. The problem how to choose between fixed price and time and materials pricing models on specific IT outsource project is really important [9]. Some suggestions how to prevent cost overruns and to reduce risk on fixed price projects are the following: technical specification writing with such deliverables as user stories, wires, clickable prototype, test plan, project plan, and a detailed estimate of the project (as the prio № 1 to choose); calculating of unpredictable risks (with at least $\sim 30 \%$, as the prio № 2), work on project agreements base that includes change order agreements (as the prio № 3). But more important is to help customer to understand what are the risks on both setups and help him to decide between those two at the very beginning. It's absolutely the best way to avoid problematic situations and complicated business relations.

\section{References}

1. https://www.pinterest.com/pin/184014334750895468/

2. http://www.slideshare.net/Iboss/a-comparison-between-time-and-material-and-fixed-bid-engagement

3. https://www.sundoginteractive.com/sunblog/posts/fixed-bid-vs.-time-and-materials-pros-and-cons

4. http://www.quora.com/What-is-the-best-web-prototyping-mockup-tool

5. http://leadinganswers.typepad.com/leading_answers/files/top_10_agile_estimation_guidelines.pdf

6. http://citeseerx.ist.psu.edu/viewdoc/download?doi=10.1.1.300.9063\&rep=rep1\&type=pdf

7. http://www.managersbuild.com/what-every-product-manager-ought-to-know-about-contract-negotiation/

8. http://en.wikipedia.org/wiki/Minimum_viable_product

9. Pressman, Roger S. (2010) Software engineering: a practitioner's approach, McGraw-Hill Education, Computers, $895 \mathrm{p}$.

\section{Olena Lisitsyna}

\section{FIXED VERSUS FLEXIBLE - GUESS WHO WINS?}

A lot of stuff has been already written about the issue of fixed price, time and materials budget models for the projects of software development. No doubt this is a really important issue that every project/product manager in IT deals with on daily basis. The reply to the question: "Why?" is very simple - it's all about money, project budget and profit of the company. A known fact is that there are three main pricing models: fixed price (or fixed scope), time and materials and body leasing. Every software outsourcing company chooses what to use in every specific case for particular customer. Every customer and vendor who works on fixed scope scenario knows what risks are coming down the road but not everybody knows how to prevent them and how to choose a proper way to go among these three at the beginning. 
The article is devoted to the problem of fixed price, time and materials pricing models on outsource projects of software development. Based on real experience of big IT company there are ready solutions how to deal with that issue and make a right choice along with how to prevent unexpected budget increase on specific project. Among necessary steps to achieve this goal there are the following ones: technical specification writing with such deliverables as user stories, wires, clickable prototypes, test plan, project plan, and a detailed estimate of the project; calculating of predictable and unpredictable risks (along with definition of the ways how to do that), the work on agreements base that includes change order agreement. The conclusion is that good communication of these preventing steps at the very beginning of project conversations is extremely important.

Keywords: outsource project, fixed price, time and materials, specification writing, unpredictable risk.

Рецензенти: О. В. Коломицева, д.е.н., професор, зав. кафедри економічної кібернетики та маркетингу Черкаського державного технологічного університету; В. О. Шиильова, д.е.н., професор, зав. кафедри економіки та менеджменту Черкаської філї ПВНЗ «Европейський університет». 